\title{
Regeneration of Ribulose 1,5-bisphosphate and Ribulose 1,5-bisphosphate carboxylase/oxygenase Activity Associated with Lack of Oxygen Inhibition of Photosynthesis at Low Temperature
}

\author{
H. SCHNYDER ${ }^{1}$,F. MÄCHLER ${ }^{2}$ AND J. NÖSBERGER \\ Institut für Pflanzenbau, Eidgenössische Technische Hochschule, Universitätstrasse 2, \\ CH-8092 Zürich, Switzerland
}

Received 29 January 1986

\begin{abstract}
Schnyder, H, Mächler, F. and Nösberger, J. 1986. Regeneration of ribulose 1,5-bisphosphate and ribulose 1,5-bisphosphate carboxylase/orygenase activity associated with lack of oxygen inhibition of photosynthesis at low temperature-J. exp. Bot. 37: 1170-1179.

The nature of the lack of oxygen inhibition of $\mathrm{C}_{3}$-photosynthesis at low temperature was investigated in white clover (Trifolium repens L.). Detached leaves were brought to steady-state photosynthesis in air $\left(34 \mathrm{~Pa} p\left(\mathrm{CO}_{2}\right), 21 \mathrm{kPa} p\left(\mathrm{O}_{2}\right)\right.$, balance $\left.\mathrm{N}_{2}\right)$ at temperatures of $20^{\circ} \mathrm{C}$ and $8^{\circ} \mathrm{C}$, respectively. Net photosynthesis, ribulose 1,5-bisphosphate (RuBP) and ATP contents, and ribulose 1,5-bisphosphate carboxylase/oxygenase (RuBPCO) activities were followed before and after changing to $20 \mathrm{kPa}$ $p\left(\mathrm{O}_{2}\right)$.

At $20^{\circ} \mathrm{C}$, lowering $p\left(\mathrm{O}_{2}\right)$ increased net photosynthesis by $37 \%$. This increase corresponded closely with the increase expected from the effect on the kinetic properties of RuBPCO. Conversely, at $8^{\circ} \mathrm{C}$ net photosynthesis rapidly decreased following a decrease in $p\left(\mathrm{O}_{2}\right)$ and then increased again reaching a steady-state level which was only $7 \%$ higher than at $21 \mathrm{kPa}\left(\mathrm{O}_{2}\right)$. The steady-state rates of $\mathrm{RuBP}$ and associated ATP consumption were both estimated to have decreased. ATP and RuBP contents decreased by $18 \%$ and $33 \%$ respectively, immediately after the change in $p\left(\mathrm{O}_{2}\right)$, suggesting that RuBP regeneration was reduced at low $p\left(\mathrm{O}_{2}\right)$ due to reduced photophosphorylation. Subsequently, RuBP content increased again. Steady-state $\mathrm{RuBP}$ content at $2.0 \mathrm{kPa} p\left(\mathrm{O}_{2}\right)$ was $24 \%$ higher than at $21 \mathrm{kPa}$ $p\left(\mathrm{O}_{2}\right)$. RuBPCO activity decreased by $22 \%$, indicating control of steady-state RuBP consumption by RuBPCO activity.

It is suggested that lack of oxygen inhibition of photosynthesis at low temperature is due to decreased photophosphorylation at low temperature and low $p\left(\mathrm{O}_{2}\right)$. This may be due to assimilate accumulation within the chloroplasts. Decreased photophosphorylation seems to decrease RuBP synthesis and RuBPCO activity, possibly due to an acidification of the chloroplast stroma.
\end{abstract}

Key words-Oxygen inhibition, photosynthesis, ribulose bisphosphate carboxylase/oxygenase.

Correspondence to: Institut für Pflanzenbau, Eidgenössische Technische Hochschule, Universitätstrasse 2, CH-8092 Zürich, Switzerland.

1 Present address: Institut für Pflanzenbau, Universität Bonn, Katzenburgweg 5, D-5300 Bonn, F.R.G.

2 To whom correspondence should be addressed.

(C) Oxford University Press 1986 


\section{INTRODUCTION}

Photosynthesis in soybean leaves and cells is inhibited by oxygen in the manner predicted from the kinetic properties of ribulose 1,5-bisphosphate carboxylase/oxygenase (RuBPCO) (Laing, Ogren, and Hageman, 1974; Servaites and Ogren, 1978). Oxygen competitively inhibits the carboxylation and promotes the oxygenation of RuBP (Ogren and Bowes, 1971; Bowes, Ogren, and Hageman, 1971). The biochemical model of $\mathrm{C}_{3}$-photosynthesis proposed by Farquhar, von Caemmerer, and Berry (1981) integrates the kinetic properties of RuBPCO with parameters describing photosynthetic electron transport capacity to predict rates of carboxylation, oxygenation and regeneration of RuBP in vivo.

However, there are physiological conditions under which net photosynthesis is not affected by oxygen as would be expected from the kinetic properties of RuBPCO. Lack of oxygen inhibition or even oxygen enhancement of photosynthesis was observed at high light intensity, low temperature, and normal $\mathrm{CO}_{2}$ partial pressure in wheat leaves (Jolliffe and Tregunna, 1968), white clover (Mächler and Nösberger, 1978), white mustard, tobacco, and tomato (Cornic and Louason, 1979). The temperature dependence of oxygen inhibition of net photosynthesis in wheat leaf segments at normal or slightly increased $p\left(\mathrm{CO}_{2}\right)$ was stronger than expected from RuBPCO kinetics (Arrabaca, Keys, and Whittingham, 1981). McVetty and Canvin (1981) found decreases in net photosynthesis after lowering $p\left(\mathrm{O}_{2}\right)$ to $2.0 \mathrm{kPa}$ at increased $p\left(\mathrm{CO}_{2}\right)$. These decreases were not due to effects of oxygen on stomatal resistance to $\mathrm{CO}_{2}$ diffusion.

Assuming an absence of effect on $\mathrm{CO}_{2}$ translocation, these deviations of $\mathrm{C}_{3}$-photosynthesis from RuBPCO kinetics have to be explained by effects of low $p\left(\mathrm{O}_{2}\right)$ either on the activity of RuBPCO or on events involved in the regeneration of RuBP. McVetty and Canvin (1981) suggested that pseudocyclic photophosphorylation may be decreased at low $p\left(\mathrm{O}_{2}\right)$. Pseudocyclic phosphorylation due to photoreduction of oxygen has been shown to be necessary for balancing ATP and NADPH requirements in mesophyll chloroplasts of $\mathrm{C}_{4}$-plants (Furbank, Badger, and Osmond, 1983). No pseudocyclic electron flow can occur in the absence of oxygen. In Chroomonas this seemed to result in over-reduction of electron carriers and an inhibition of cyclic electron flow (Suzuki and Tomoyoshi, 1984a, b). Inhibition of cyclic and pseudocyclic phosphorylation in the absence of oxygen could be a reason for ATP deficiency and decreased $\mathrm{CO}_{2}$ fixation (Heber, Egneus, Hanck, Jensen, and Köster, 1978).

However, Sharkey (1985) found that a lack of $\mathrm{O}_{2}$-inhibition of photosynthesis was always associated with a failure of increased $\mathrm{CO}_{2}$ pressure to stimulate photosynthesis to the expected degree. Our data confirm this for the lack of $\mathrm{O}_{2}$-inhibition at low temperature (Schnyder, 1984), and support an alternative explanation which is related to the concentration of inorganic phosphate $\left(P_{i}\right)$ in the chloroplast stroma (Sharkey, 1985). Photophosphorylation may be limited by $P_{i}$ when organic phosphate levels increase due to an inbalance between $\mathrm{CO}_{2}$ assimilation and assimilate export at high light intensity, low temperature, high $p\left(\mathrm{CO}_{2}\right)$ and low $p\left(\mathrm{O}_{2}\right)$.

On the other hand, Schnyder, Mächler, and Nösberger (1984) found that decreased oxygen inhibition at low temperature was associated with partial deactivation of RuBPCO at low $p\left(\mathrm{O}_{2}\right)$.

The following experiment was designed to shed light on this oxygen effect. Leaves of white clover (Trifolium repens $\mathrm{L}$.) were pre-adapted in air to temperatures at which photosynthesis was expected to respond to low $p\left(\mathrm{O}_{2}\right)$ either according to $\mathrm{RuBPCO}$ kinetics $\left(20^{\circ} \mathrm{C}\right)$ or deviating from RuBPCO kinetics $\left(8^{\circ} \mathrm{C}\right)$. After steady-state photosynthesis was attained, the $p\left(\mathrm{O}_{2}\right)$ was decreased from 21 to $2.0 \mathrm{kPa}$ to study the time course of net photosynthesis, RuBP and ATP contents and RuBPCO activity. 


\section{MATERIALS AND METHODS}

Plant material

White clover plants (Trifolium repens L., ecotype Chur) were propagated vegetatively and grown in pots (15 cm diameter) filled with perlite. The pots were placed in growth chambers (PGV-36, Conviron) at day/night temperatures of $20 / 16^{\circ} \mathrm{C}$. Relative humidity was $75 / 80 \%$ (day/night). The photoperiod was $16 \mathrm{~h}$ with light being provided by a bank of fluorescent tubes and incandescent bulbs giving an irradiance of $400 \mu \mathrm{mol}$ quanta $\mathrm{m}^{-2} \mathrm{~s}^{-1}(400-700 \mathrm{~nm})$ at plant height. Plants were irrigated daily with nutrient solution (Hammer, Tibbits, Langhans, and McFarlane, 1978). The leaves used in the experiments had reached full expansion 6-12 d before sampling.

\section{Gas exchange measurements}

$\mathrm{CO}_{2}$ exchange was measured using an open infrared gas analysis system. One leaf was detached during the photoperiod and placed in a temperature controlled cuvette of brass and perspex having a volume of $12 \mathrm{~cm}^{3}$. Light was provided by a $400 \mathrm{~W}$ sodium vapour lamp separated from the cuvette by an $8.0 \mathrm{~cm}$ layer of water. Light intensity at the leaf surface was $430 \mu$ mol quanta $\mathrm{m}^{-2} \mathrm{~s}^{-1}(400-700 \mathrm{~nm})$. Temperature was either $20^{\circ} \mathrm{C}$ or $8^{\circ} \mathrm{C}$. The leaf was pre-adapted in air $\left(21 \mathrm{kPa} p\left(\mathrm{O}_{2}\right), 34 \mathrm{~Pa} p\left(\mathrm{CO}_{2}\right)\right.$, balance $\mathrm{N}_{2}$ ) until steady-state photosynthesis was established (about $30 \mathrm{~min}$ ). Then a gas mixture with $2.0 \mathrm{kPa} p\left(\mathrm{O}_{2}\right)$ and $34 \mathrm{~Pa} p\left(\mathrm{CO}_{2}\right)$ prepared by Wösthoff pumps was forced through the cuvette. Gas flow was $1000 \mathrm{~cm}^{3} \mathrm{~min}^{-1}$. The decrease in $\mathrm{CO}_{2}$ concentration due to photosynthesis was monitored by an IRGA Binos 1 (Leybold-Heraeus) used in the differential mode.

\section{Determination of $A T P$ and $R u B P$ content}

Excised leaves were pre-adapted as indicated for gas exchange measurements using a cuvette of brass and glass with a volume of $250 \mathrm{~cm}^{3}$ and containing a fan. Leaves were rapidly removed from the cuvette after different lengths of time at $2.0 \mathrm{kPa} p\left(\mathrm{O}_{2}\right)$, frozen in liquid nitrogen and extracted as described by Perchorowicz and Jensen (1983). Chlorophyll was estimated according to Bruinsma (1963). ATP was measured by the luciferase method using the luminometer and assay chemicals from LKB Wallac (Turku, Finland). RuBP was measured according to the method of Latzko and Gibbs (1974) using RuBPCO prepared according to Mächler and Nösberger (1984).

\section{Determination of the activation state of RuBPCO}

Excised leaves were pre-adapted as described for ATP and RuBP determination, rapidly removed from the cuvette, and RuBPCO rapidly extracted and tested as described earlier (Mächler and Nōsberger, 1980).

\section{RESULTS AND DISCUSSION}

\section{Net photosynthesis}

The response of net photosynthesis to a change in $p\left(\mathrm{O}_{2}\right)$ from 21 to $2.0 \mathrm{kPa}$ was affected by temperature (Fig. 1). Net photosynthesis increased by about $37 \%$ at $20^{\circ} \mathrm{C}$, whereas at $8{ }^{\circ} \mathrm{C}$ it increased by only $7 \%$. Net photosynthesis at $8{ }^{\circ} \mathrm{C}$ showed a complex oscillating response to the decrease in $p\left(\mathrm{O}_{2}\right)$. A slight initial increase was followed by a strong decrease, a second increase, and a second decrease. Then net photosynthesis increased slowly attaining a new steady-state after 12-15 min. A similar oscillating time course of net photosynthesis following a change in oxygen partial pressure from 21 to $2.0 \mathrm{kPa}$ was found by McVetty and Canvin (1981) at high $\mathrm{CO}_{2}$ concentration.

\section{RuBP consumption}

The consumption of RuBP is due in part both to photosynthetic $\mathrm{CO}_{2}$ fixation and to photorespiratory oxygen fixation. RuBP consumption can be calculated from net photosynthesis $(F)$, the partial pressures of $\mathrm{O}_{2}(O)$ and $\mathrm{CO}_{2}(C)$ and the substrate specificity factor of $\operatorname{RuBPCO}(S)$. $S$ has been determined for white clover by Lehnherr, Mächler, and Nösberger 


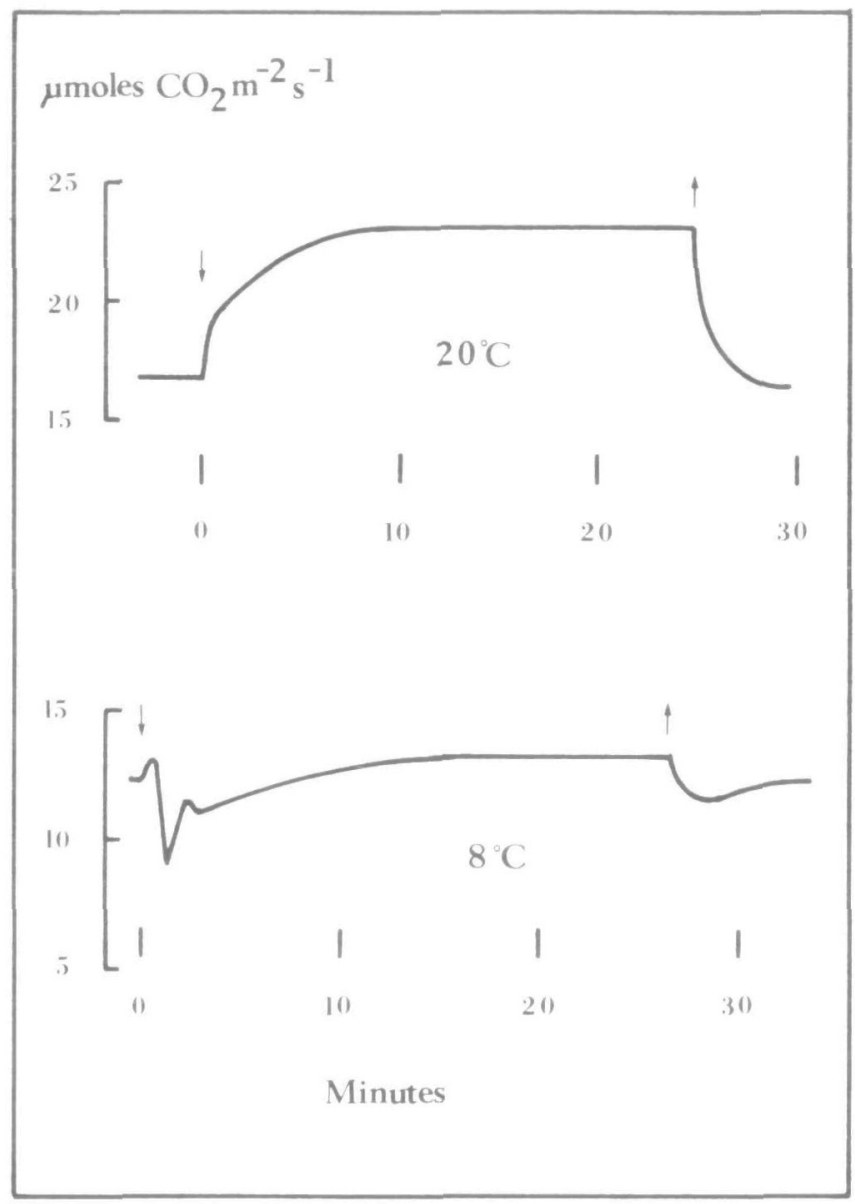

FIG. 1. Time-course of net photosynthesis during a change in $\mathrm{O}_{2}$ partial pressure from 21 to 2.0 to $21 \mathrm{kPa}$ at $20^{\circ} \mathrm{C}$ and $8{ }^{\circ} \mathrm{C}$. Curves represent typical recorder tracing. Changes in oxygen partial pressure are indicated by arrows.

(1985) and is 75 independent of temperature. $F$ and $S$ are related to the velocities of carboxylation $\left(v_{\mathrm{c}}\right)$ and oxygenation $\left(v_{0}\right)$ of RuBP by equations 1 and 2 .

$$
\begin{gathered}
F=v_{\mathrm{c}}-\frac{1}{2} v_{\mathrm{o}} \\
S=v_{\mathrm{c}} / v_{\mathrm{o}} \cdot O / C .
\end{gathered}
$$

In equation 1 oxygenation of $\mathrm{RuBP}$ is related to photorespiratory $\mathrm{CO}_{2}$ release. Fixation of one molecule of $\mathrm{O}_{2}$ is followed by the release of half a molecule of $\mathrm{CO}_{2}$ due to glycine decarboxylation in the glycolate pathway (Ogren and Chollet, 1982). Dark respiration is ignored. Equation 2 is according to Laing et al. (1974) and Jordan and Ogren (1981). RuBP consumption $\left(v_{c}+v_{\mathrm{o}}\right)$ can be calculated by equation 3 , which follows from equation 1 and 2 :

$$
v_{\mathrm{c}}+v_{\mathrm{o}}=\frac{F}{1-\frac{O}{2 S C}}+\frac{F}{\frac{S C}{O}-\frac{1}{2}}
$$




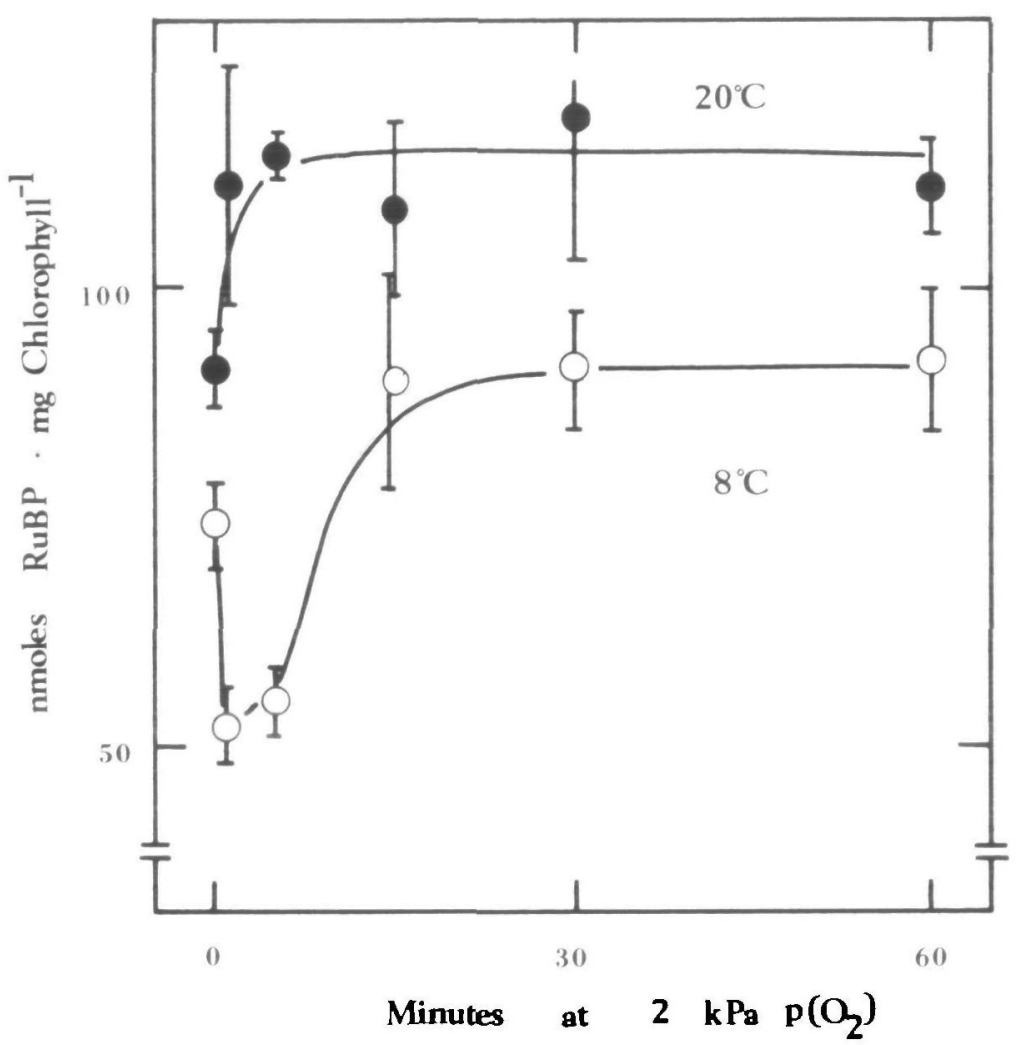

FIG. 2. Tim-course of RuBP content in leaves following a decrease in $\mathrm{O}_{2}$ partial pressure from 21 to $20 \mathrm{kPa}$ at $20^{\circ} \mathrm{C}(\bullet)$ and $8^{\circ} \mathrm{C}(0)$. Vertical bars indicate $2 \times$ standard errors of means.

The decrease in $p\left(\mathrm{O}_{2}\right)$ from 21 to $2.0 \mathrm{kPa}$ was calculated to decrease RuBP consumption per net $\mathrm{CO}_{2}$ fixed by $31 \%$ and $28 \%$ at $20^{\circ} \mathrm{C}$ and $8{ }^{\circ} \mathrm{C}$ respectively. The difference between temperatures is due to a change in the ratio of the solubilities of $\mathrm{O}_{2}$ to $\mathrm{CO}_{2}$. The higher efficiency of photosynthetic RuBP consumption at decreased $p\left(\mathrm{O}_{2}\right)$ is calculated to allow for a $45 \%\left(20^{\circ} \mathrm{C}\right)$ and $39 \%\left(8{ }^{\circ} \mathrm{C}\right)$ increase in net $\mathrm{CO}_{2}$ fixation if $\mathrm{RuBP}$ consumption is constant. However, steady-state photosynthesis at $2.0 \mathrm{kPa} p\left(\mathrm{O}_{2}\right)$ was only increased by $37 \%$ and $7 \%$ at $20^{\circ} \mathrm{C}$ and $8{ }^{\circ} \mathrm{C}$ respectively. Thus steady-state RuBP consumption was calculated to be reduced slightly $(-5 \%)$ at $20^{\circ} \mathrm{C}$ and significantly $(-24 \%)$ at $8^{\circ} \mathrm{C}$.

\section{RuBP content}

The RuBP content in leaves at $20^{\circ} \mathrm{C}$ increased by $24 \%$ within $1-5$ min when oxygen partial pressure was decreased from 21 to $2.0 \mathrm{kPa}$ (Fig. 2). This result is consistent with the findings of Bourquin and Fock (1983). In their experiments, steady-state levels of RuBP were much higher at $20 \mathrm{kPa}$ than at $21 \mathrm{kPa} p\left(\mathrm{O}_{2}\right)$ if $p\left(\mathrm{CO}_{2}\right)$ was low. At high $p\left(\mathrm{CO}_{2}\right) \mathrm{RuBP}$ levels were similar at low and air level $p\left(\mathrm{O}_{2}\right)$. Our results and the data of Bourquin and Fock (1983) suggest that the $24 \%$ increase in RuBP content at $2.0 \mathrm{kPa} p\left(\mathrm{O}_{2}\right)$ and limiting $p\left(\mathrm{CO}_{2}\right)$ found at $20^{\circ} \mathrm{C}$ was due to the decrease in RuBP consumption.

At $8^{\circ} \mathrm{C}$, RuBP content decreased immediately by one third after the change in oxygen partial pressure and then increased to attain a steady-state level after 15 min which was $24 \%$ higher than the level at $21 \mathrm{kPa} p\left(\mathrm{O}_{2}\right)$. The transitional decrease in RuBP content was 


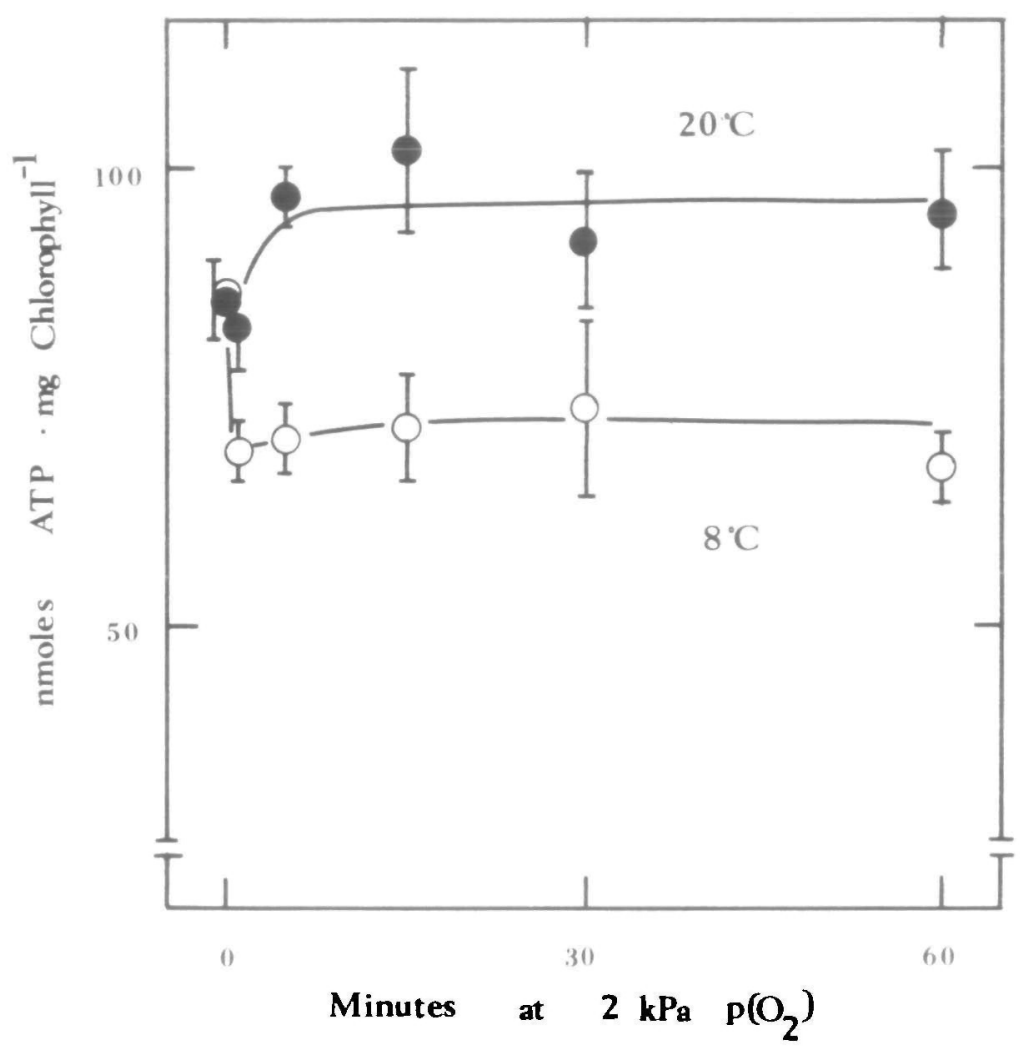

FIG. 3. Time-course of ATP content in leaves following a decrease in $\mathrm{O}_{2}$ partial pressure from 21 to $2.0 \mathrm{kPa}$ at $20^{\circ} \mathrm{C}(\mathrm{O})$ and $8^{\circ} \mathrm{C}(\mathrm{O})$. Vertical bars indicate $2 \times$ standard errors of means.

associated with decreased RuBP consumption (see above) indicating reduced RuBP regeneration and limitation of photosynthesis by $\mathrm{RuBP}$.

\section{ATP content}

The ATP content in leaves at $20^{\circ} \mathrm{C}$ increased by $11 \%$ when oxygen partial pressure was decreased from 21 to $2.0 \mathrm{kPa}$ (Fig. 3). At $8{ }^{\circ} \mathrm{C}$ it dropped immediately by $18 \%$ when oxygen was decreased and did not increase again under steady-state conditions. ATP content as determined in our experiments included a component which was contained in the chloroplast stroma and another component which was contained in other cell compartments. However, it is suggested that oxygen effects on the ATP content as shown in our experiments are due to photosynthesis and reflect changes in the stromal component. Oxygen affects the carbon flow and thus ATP consumption in the Calvin cycle and can affect pseudocyclic and cyclic photophosphorylation. Conversely, ATP synthesis associated with dark respiration in the mitochondria is independent of oxygen above $2.0 \mathrm{kPa} p\left(\mathrm{O}_{2}\right)$ (Forrester, Krotkov, and Nelson, 1966).

RuBP regeneration from the products of RuBP oxygenation needs slightly more ATP than $\mathrm{RuBP}$ regeneration from the products of RuBP carboxylation. This is due to the need of extra ATP for the phosphorylation of glycerate. Thus the increase in ATP content at $20^{\circ} \mathrm{C}$ after a decrease in oxygen (Fig. 3) may be due to a decrease in ATP consumption partly because of an increase in the ratio of carboxylation to oxygenation and partly because of a $7 \%$ decrease 
in RuBP consumption (see above). The decrease in ATP content at $8^{\circ} \mathrm{C}$ following the decrease in $p\left(\mathrm{O}_{2}\right)$ was associated with a $24 \%$ decrease in RuBP consumption and, due to increased ratio of carboxylation to oxygenation, with an even greater decrease in ATP consumption indicating decreased ATP synthesis. It is suggested that this decrease in ATP synthesis at $8^{\circ} \mathrm{C}$ and low $p\left(\mathrm{O}_{2}\right)$ caused the transitory decrease in RuBP content (Fig. 2) by decreasing RuBP regeneration.

The decrease in photophosphorylation at decreased $p\left(\mathrm{O}_{2}\right)$ could be due to a decreased content of $P_{i}$ in the chloroplast stroma. Oxygenation of RuBP causes enhanced release of $P_{1}$ in the chloroplast due to dephosphorylation of phosphoglycolate. This may increase the concentration of $P_{i}$ in the chloroplast stroma and enhance photophosphorylation (Viil, Ivanova, and Pärnik, 1985). Product inhibition of photosynthesis due to increased levels of organic phosphates and decreased $P_{1}$ in the chloroplast stroma seems to occur more easily in the absence of oxygen than in its presence since less $P_{i}$ in the chloroplastic environment is required for assimilate export from chloroplasts if $p\left(\mathrm{O}_{2}\right)$ is increased (Usuda and Edwards, 1982). The risk of product inhibition of photosynthesis due to decreased assimilate export from chloroplasts increases as temperature is decreased: A higher $\mathrm{P}_{1}$ level in the chloroplastic environment is required for assimilate export from chloroplasts if temperature is low (Mächler, Schnyder, and Nösberger, 1984). Thus both low temperature and low $p\left(\mathrm{O}_{2}\right)$ seem to decrease assimilate export from chloroplasts. Product inhibition of photosynthesis is consequently especially severe when the two effects are superimposed.

\section{Activation state of $R u B P C O$}

The activation state of RuBPCO in leaves at $20^{\circ} \mathrm{C}$ was not significantly affected by the decrease in $p\left(\mathrm{O}_{2}\right)$ (Fig. 4). Conversely a change from 21 to $2.0 \mathrm{kPa} p\left(\mathrm{O}_{2}\right)$ in leaves at $8{ }^{\circ} \mathrm{C}$ caused partial deactivation of RuBPCO. After $60 \mathrm{~min}$ at $2.0 \mathrm{kPa} p\left(\mathrm{O}_{2}\right) \mathrm{RuBPCO}$ activity attained a constant level which was $22 \%$ lower than at $21 \mathrm{kPa} p\left(\mathrm{O}_{2}\right)$.

This decrease in $\mathrm{RuBPCO}$ activation seems to be responsible for the low $\mathrm{CO}_{2}$ fixation rate despite high RuBP content under steady-state conditions at $8^{\circ} \mathrm{C}$ and low $p\left(\mathrm{O}_{2}\right)$. The initial decrease in RuBP content following the decrease in $p\left(\mathrm{O}_{2}\right)$ at $8{ }^{\circ} \mathrm{C}$ (Fig. 2) was followed by a $15 \mathrm{~min}$ increase. This increase in RuBP content was obviously associated with a slow decrease in RuBPCO activity (Fig. 4) suggesting that initial limitation of photosynthesis by RuBP was relieved by limitation due to decreased RuBPCO activity. However, the decrease in RuBPCO activity appeared to be much slower than the increase in RuBP content. This may be due to the assay procedure for RuBPCO activity. The RuBPCO assay measures the active enzyme- $\mathrm{CO}_{2}-\mathrm{Mg}^{++}$form plus the inactive enzyme- $\mathrm{CO}_{2}$ form of $\mathrm{RuBPCO}$ (Schnyder et al., 1984). The enzyme- $\mathrm{CO}_{2}$ form may not be present in significant amounts under steady-state conditions (Curry, Pierce, Tolbert, and Orme-Johnson, 1981). However, it may increase when RuBPCO is being inactivated, since the dissociation of $\mathrm{CO}_{2}$ from the enzyme is much slower than the dissociation of $\mathrm{Mg}^{++}$from the active form. Thus the steady-state equilibrium may be estalished only slowly, especially if temperature is low. Therefore, it is suggested that, after the decrease in $p\left(\mathrm{O}_{2}\right), \mathrm{RuBPCO}$ activity was overestimated at first in our experiment.

Control of photosynthesis by RuBPCO activity at decreased rates of RuBP regeneration has also been found by Perchorowicz, Raynes, and Jensen (1981) and by Mott, Jensen, O'Leary, and Berry (1984) at low light intensity. A decrease in light intensity was followed by a transitory decrease and then by an increase in RuBP content which was associated with a decrease in RuBPCO activity.

Deactivation of RuBPCO has been found in isolated chloroplasts when assimilate export was decreased due to a low concentration of $P_{i}$ in the medium (Mächler and Nösberger, 


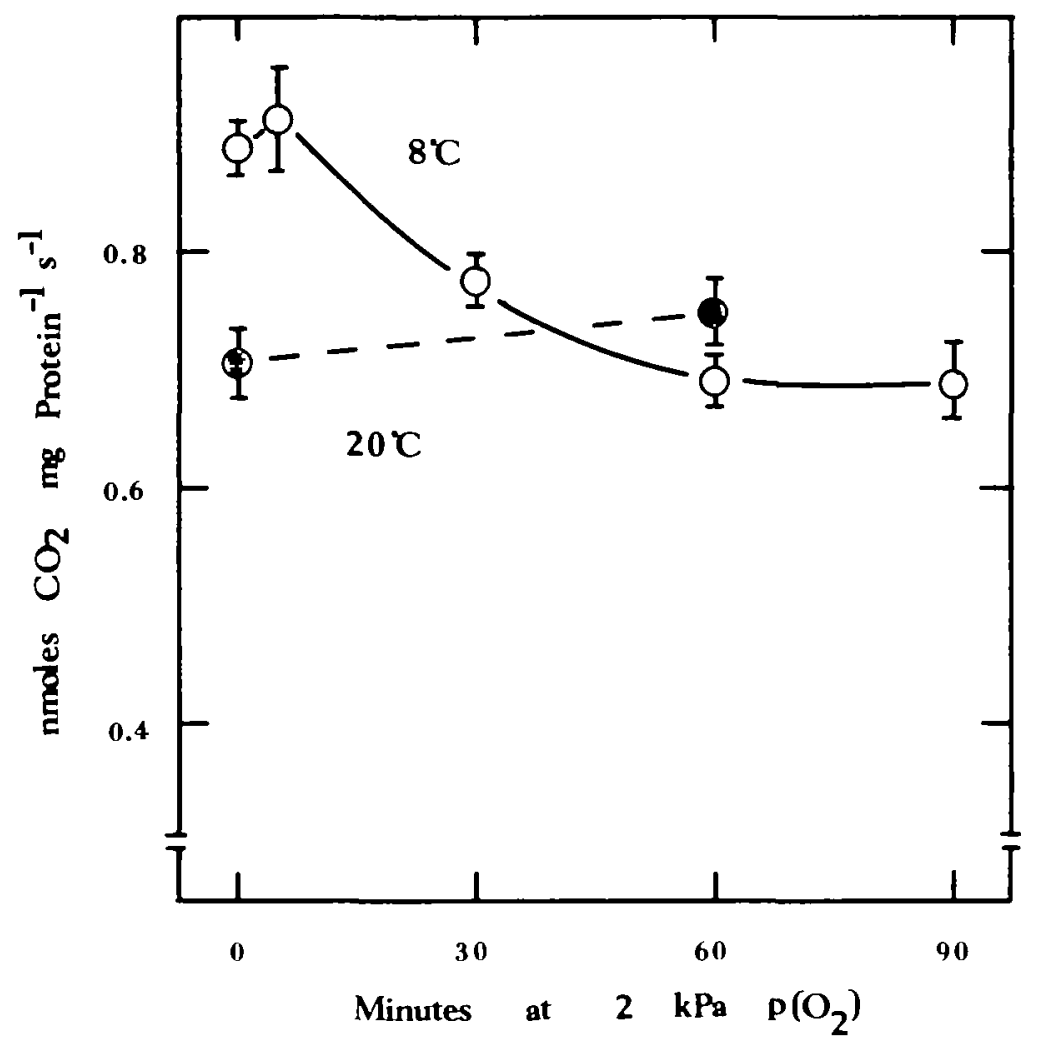

FIG. 4. Time-course of the activation state of $\mathrm{RuBPCO}$ in leaves following a dectease in $\mathrm{O}_{2}$ partial pressure from 21 to $2.0 \mathrm{kPa}$ at $20^{\circ} \mathrm{C}(\mathrm{O})$ and $8^{\circ} \mathrm{C}(\mathrm{O})$. RuBPCO activity was assayed at $10^{\circ} \mathrm{C}$ after rapid extraction. Vertical bars indicate $2 \times$ standard errors of means.

1984). Deactivation of RuBPCO was associated with an accumulation of organic phosphates and a decrease in the ATP content within the chloroplasts and with increased export of 3-phosphoglycerate instead of dihydroxyacetonephosphate (Mächler et al., 1984). Decreased ATP content and preferential export of 3-phosphoglycerate suggested that stromal pH could be decreased and that deactivation of RuBPCO was due to this $\mathrm{pH}$ change. A similar mechanism of deactivation of RuBPCO could be suggested for leaves at low $p\left(\mathrm{O}_{2}\right)$ and low temperature if it can be assumed that stromal $P_{\mathfrak{l}}$ concentration is decreased.

\section{CONCLUSION}

Decreased RuBP and ATP consumption, decreased ATP content and initially decreased $\mathrm{RuBP}$ content in leaves at $8^{\circ} \mathrm{C}$ after a change from 21 to $2.0 \mathrm{kPa} p\left(\mathrm{O}_{2}\right)$ suggest a decrease in ATP synthesis and a decrease in $\mathrm{RuBP}$ regeneration. The initial limitation of photosynthesis by RuBP was subsequently relieved as RuBPCO activity decreased. It is suggested that the decrease in ATP synthesis was due to decreased stromal concentration of $P_{i}$ because of assimilate accumulation. This may bring about inactivation of RuBPCO possibly due to a decrease in $\mathrm{pH}$.

\section{ACKNOWLEDGEMENTS}

This work was supported by the Swiss National Science Foundation. The authors thank Ms. Allenbach who grew the plants and Ms. Schoenberg who checked the English translation. 


\section{LITERATURE CITED}

Arrabaca, M. C., Keys, A. J., and Whittingham, C. P., 1981. Effect of temperature on photosynthetic and photorespiratory metabolism. In Proceedings of the fifth international photosynthesis congress, Volume 4. Ed. G. Akoyunoglou. Balaban International Science Services. Philadelphia. Pp. 463-70.

Bourquin, P. W., and Fock, H. P., 1983. Effects of irradiance, $\mathrm{CO}_{2}$ and $\mathrm{O}_{2}$ on photosynthetic rate and on levels of ribulose 1,5-bisphosphate and glycolate in sunflower leaves. Photosynthetica, 17, $182-8$.

Bowes, G., Ogren, W. L., and Hageman, R. H., 1971. Phosphoglycolate production catalyzed by ribulose diphosphate carboxylase. Biochemical and Biophysical Research Communications, 45, $716-22$.

BRuinsma, J., 1963. The quantitative analysis of chlorophylls $\mathrm{a}$ and $\mathrm{b}$ in plant extracts. Photochemistry and Photobiology, 2, 241.

Cornic, G., and Lounson, G., 1980. The effects of $\mathrm{O}_{2}$ on net photosynthesis at low temperature $\left(5^{\circ} \mathrm{C}\right)$. Plant, Cell and Environment, 3, 149-57.

Curry, S. D., Pifrce, J., Tolbert, N. E., and Orme-Johnson, W. H., 1981. On the mechanism of effector-mediated activation of ribulose bisphosphate carboxylase oxygenase. Journal of Biological Chemistry, 256, 6623-8.

FARQuhar, G. D., von CAEMmerer, S., and BerRy, J. A., 1980. A biochemical model of photosynthetic $\mathrm{CO}_{2}$ assimilation in leaves of $\mathrm{C}_{3}$ species. Planta, 149, 78-90.

Forrester, M. L., Krotkov, G., and Nelson, C. D., 1966. Effect of oxygen on photosynthesis and photorespiration in detached leaves. I. Soybean. Plant Physiology, 41, 422-7.

Furbank, R. T., BADGer, M. R., and Osmond, C. B., 1983. Photoreduction of oxygen in mesophyll chloroplasts of $\mathrm{C}_{4}$ plants. A model system for studying an in vivo mehler reaction. Ibid. 73, 1038-41.

Hammer, P. A., Tibbits, T. W., Langhans, R. W., and McFarlane, J. C., 1978. Base line growth studies of 'Grand Rapids' lettuce in controlled environment. Journal of the American Society of Horticultural Science, 103, 649-55.

Heber, U., Egneus, H., Hanck, U., Jensen, M., and Köster, S., 1978. Regulation of photosynthetic electron transport and photophosphorylation in intact chloroplasts and leaves of Spinacia oleracea L. Planta, 143, 41-9.

Jolliffe, P. A., and Tregunns, E. B., 1968. Effect of temperature, $\mathrm{CO}_{2}$ concentration, and light intensity on oxygen inhibition of photosynthesis in wheat leaves. Plant Physiology, 43, 902-6.

JORDAN, D. B., and OGREN, W. L., 1981. Species variation in the specificity of ribulose bisphosphate carboxylase oxygenase. Nature, 291, 513-15.

LAing, W. A., OGREN, W. L., and Hageman, R. H., 1974. Regulation of soybean net photosynthetic $\mathrm{CO}_{2}$ fixation by interaction of $\mathrm{CO}_{2}, \mathrm{O}_{2}$, and ribulose 1,5-bisphosphate carboxylase. Plant Physiology, 54, 678-85.

LATzKo, E., and GibBs, M., 1974. D-Ribulose-1,5-diphosphat und Pentosemonophosphat. In Methoden der enzymatischen Analyse. Ed. H. U. Bergmeyer. Verlag Chemie, Weinheim.

LeHNHERR, B., MÃCHLER, F., and NŌSBERGER, J., 1985. Influence of temperature on the ratio of ribulose bisphosphate carboxylase to oxygenase activities and on the ratio of photosynthesis to photorespiration of leaves. Journal of Experimental Botany, 36, 1117-25.

MÄCHLer, F., and NösBerger, J., 1978. The adaptation to temperature of photorespiration and of the photosynthetic carbon metabolism of altitudinal ecotypes of Trifolium repens L. Oecologia, $35,267-76$.

1980. Regulation of ribulose bisphosphate carboxylase activity in intact wheat leaves by light, $\mathrm{CO}_{2}$, and temperature. Journal of Experimental Botany, 31, 1485-91.

1984. Influence of inorganic phosphate on photosynthesis of wheat chloroplasts. II. Ribulose bisphosphate carboxylase activity. Ibid. 35, 488-94.

- SCHNYDER, H., and NÖSBERGER, J., 1984. Influence of inorganic phosphate on photosynthesis of wheat chloroplasts. I. Photosynthesis and assimilate export at $5^{\circ} \mathrm{C}$ and $25^{\circ} \mathrm{C}$. Ibid. 35 , $481-7$.

MCVetTY, P. B. E., and CAnvin, D. T., 1981. Inhibition of photosynthesis by low oxygen concentrations. Canadian Journal of Botany, 59, 721-5.

Mott, K. A., Jensen, R. G., O'Leary, J. W., and Berry, J. A., 1984. Photosynthesis and ribulose 1,5-bisphosphate concentrations in intact leaves of Xanthium strumarium L. Plant Physiology, 76, $968-71$. 
OGREN, W. L., and BowEs, G., 1971. Ribulose diphosphate carboxylase regulates soybean photorespiration. Nature, 230, 159-60.

- and ChOLlet, R., 1982. Photorespiration. In Photosynthesis, Volume 2. Ed. Govindjee. Academic Press, New York, London. Pp. 191-230.

Perchorowicz, J. T., and Jensen, R. G., 1983. Photosynthesis and activation of ribulose bisphosphate carboxylase in wheat seedlings. Plant Physiology, 71, 955-60.

- RAYNes, D. A., and JeNSEN, R. G., 1981. Light limitation of photosynthesis and activation of ribulose bisphosphate carboxylase in wheat seedlings. Proceedings of the National Academy of Science of the U.S.A., 78, 2985-9.

SCHNYDER, H., 1984. Der Einfluss des Aktivierungszustandes und der katalytischen Eigenschaften der Ribulose-1,5-bisphosphat Carboxylase/Oxygenase auf die Photosynthese intakter Blätter von Weissklee (Trifolium repens L.). Ph.D. thesis, Eidgenössische Technische Hochschule, Zürich.

- MÄCHLER, F., and NósBerger, J., 1984. Influence of temperature and oxygen concentration on photosynthesis and light activation of ribulose bisphosphate carboxylase oxygenase in intact leaves of white clover (Trifolium repens L.). Journal of Experimental Botany, 35, 147-56.

ServatTes, J. C., and OGRen, W. L., 1978. Oxygen inhibition of photosynthesis and stimulation of photorespiration in soybean leaf cells. Plant Physiology, 61, 62-7.

SharkEY, T. D., 1985. $O_{2}$-insensitive photosynthesis in $C_{3}$ plants. Its occurrence and a possible explanation. Ibid. 78, 71-5.

Suzuki, K., and Tomoyoshi, I., 1984a. Effect of oxygen on photosynthetic ${ }^{14} \mathrm{CO}_{2}$ fixation in Chroomonas sp. (Cryptophyta). I. Some characteristics of the oxygen effect. Plant and Cell Physiology, 25, 367-75.

$1984 b$. Effect of oxygen on photosynthetic ${ }^{14} \mathrm{CO}_{2}$ fixation in Chroomonas sp. (Cryptophyta). II. Effects of inhibitors, uncouplers and an artificial electron mediator on the inhibition of ${ }^{14} \mathrm{CO}_{2}$ fixation by anaerobiosis. Ibid. 25, 377-84.

USUDA, H., and EDWARDS, G. E., 1982. Influence of varying $\mathrm{CO}_{2}$ and orthophosphate concentrations on the rates of photosynthesis and synthesis of glycolate and dihydroxyacetone phosphate by wheat chloroplasts. Plant Physiology, 69, 469-73.

VIIL, J., Ivanova, H., and PÄrNIK, T., 1985. Effects of $\mathrm{O}_{2}$ and irradiance on $\mathrm{CO}_{2}$ assimilation in Phaseolus vulgaris. Photosynthetica, 19, 88-97. 